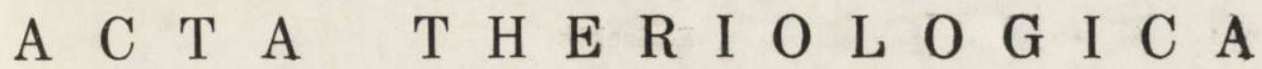

\section{Age Estimation of Roe-Deer from Different Hunting-Grounds of South-Eastern Poland}

\author{
[With 2 Tables \& 7 Figs.]
}

\begin{abstract}
From among 1506 mandibles of roe-deer bucks, Capreolus capreolus (L in n a e u s, 1758), shot in south-eastern Poland in the years 1969-1971 200 mandibles were selected. They derived from four different habitats. The age of these bucks was estimated at first on the basis of teeth wear, and then determined absolutely according to the number of winter rings in tooth cement $I_{1}$. Estimates of age obtained by these two methods agreed in barely $20-40 \%$. Overestimation of buck age on the basis of teeth wear in younger classes ( 1 to 4 years) amounts to approximately 1 year, while in older age classes (5 to 9 years) it reaches $2-4$ years. Smaller errors of relative age estimates were found for bucks living in highland and mountain areas, in comparison with those animals living in lowland habitats. The rate of teeth wear in roe-deer depends directly on tooth hardness and quality of consumed food. This is related to mineral contents of soil in a given area. Moreover, there exists certain individual variability in teeth wear of roe-deer buck deriving from one habitat. Errors of estimates made by hunting commisions are higher than those made by a selected specialist, although the trend of deviations is similar in both cases.
\end{abstract}

\section{INTRODUCTION}

In Poland hunting economy concerning the game is based to a considerable degree on selective shooting. This depends on the removal in the first instance of the reproductors showing little value for further breeding. This value of roe-deer or deer bucks is estimated by the quality of antlers in a given age class ( $\mathrm{P}$ i e low ski, 1970; $\mathrm{P}$ a s $ł$ aw$\mathrm{ski}$, 1971). Selective economy may be efficient only in this case when the estimation of the animal age is correct. It was repeatedly reported that the relative estimation of age employed up to date and based on the teeth wear is not sufficiently accurate (B r i a n, 1966). Hitherto only the histological method depending on the determination of the number of annual growth rings in tooth cement permits for the absolute esti- 
mation of the age. This method for deer was eleborated several years ago (M c Ewan, 1963; Low \& Cowan, 1963) but in Poland has not been employed as yet.

This study was aimed at the comparison of the commonly used method of estimation of the animal age, based on teeth wear, with absolute determinations. Additionally, the effect of various habitats on the degree of teeth weer was investigated. Relative estimates of the age made by hunting commissions were compared with the estimates made by one specialist. All these data permitted to determine the accuracy of age estimates employed for bucks.

\section{MATERIAL AND METHODS}

Mandibles of bucks shot in south-eastern Poland $(N=1506)$, in the provinces of Katowice, Kraków and Rzeszów, were collected for the investigations. The material was obtained in the years 1969, 1970 and 1971 on the annual sessions of the Provincial Hunting Councils and in the Provincial Boards of State Forests. During the sessions hunters present complete skulls of all shot bucks and the commision estimates whether the shooting was made in accordance with the rules. From majority of the presented skulls the mandibles with complete teeth are

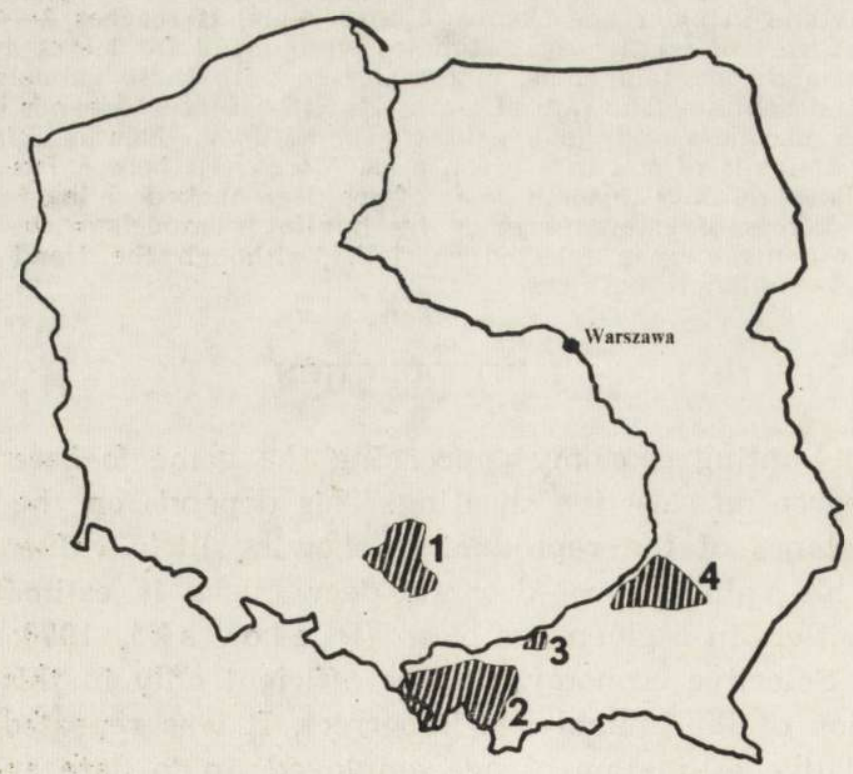

Fig. 1. Four areas selected for the studies on the age of bucks drawn on the background of forest map in south-eastern Poland.

1 - Silesian Upland, 2 - Western Beskidy, 3 - Niepołomicka Forest, 4 - Sandomierska Forest. 
left while hunters retain the trophies. The date and place of shooting (numbers of hunting districts and forest districts), as well as the age estimated by the commission on the basis of teeth weer ( $\mathrm{Pielowski,1970)}$ were noted directly on the mandibles.

For the investigations four smaller areas were selected, representing distinctly different habitats ( $\mathrm{Sz}$ a f e r, 1959). Two of them belong to highlands or mountains, the other two - to lowlands (Fig. 1).

(1). Silesian Upland - its eastern part lying in the river basin of the upper flow of Mała Panew and Liswarta. There occur mainly podzol soils formed from sandy-loamy soils, as well as podzols on loose sands, and brown soils on loams, This area is covered by not too dense complexes of pine forests (Vaccinio myrtilli-Pinetum) and mixed forests (Pino-Quercetum).

(2). Western Beskidy - ranges of Beskid Sląski, Żywiecki and Sredni, which form mountain area, uniform in respect of soil and plant cover. On the mountain soils there occur mainly subalpine forests: fir-beech forests (Fagetum carpaticum) and fir-spruce forests (Piceetum abietetosum).

Table 1

Material of buck mandibles from four areas selected for the investigations (cf. Fig. 1). $M$ - total material from a given area, $A-$ material examined by histological method.

\begin{tabular}{|c|c|c|c|c|c|c|c|c|}
\hline \multirow{2}{*}{$\begin{array}{c}\text { Age } \\
\text { (years) }\end{array}$} & \multicolumn{2}{|c|}{$\begin{array}{l}\text { Silesian } \\
\text { Upland }\end{array}$} & \multicolumn{2}{|c|}{$\begin{array}{c}\text { Beskid } \\
\text { Mountains }\end{array}$} & \multicolumn{2}{|c|}{$\begin{array}{l}\text { Niepolomick a } \\
\text { Forest }\end{array}$} & \multicolumn{2}{|c|}{$\begin{array}{c}\text { Sandomierska } \\
\text { Forest }\end{array}$} \\
\hline & $M$ & $A$ & $M$ & $A$ & $M$ & $A$ & $M$ & $A$ \\
\hline 1 & 0 & 0 & 14 & 5 & 2 & 1 & 0 & 0 \\
\hline 2 & 9 & 4 & 44 & 11 & 4 & 3 & 1 & 0 \\
\hline 3 & 30 & 8 & 79 & 13 & 11 & 6 & 5 & 3 \\
\hline 4 & 29 & 9 & 93 & 13 & 16 & 7 & 7 & อ \\
\hline 5 & 18 & 6 & 51 & 12 & 11 & 3 & 9 & 5 \\
\hline 6 & 14 & 6 & 39 & 14 & 13 & 10 & 4 & 2 \\
\hline 7 & 7 & 5 & 27 & 8 & 7 & 3 & 2 & 0 \\
\hline 8 & 4 & 4 & 13 & 6 & 5 & 2 & 6 & 2 \\
\hline 9 & 9 & 6 & 20 & 9 & 11 & 6 & 6 & 3 \\
\hline Total & 120 & 48 & 380 & 91 & 80 & 41 & 40 & 20 \\
\hline
\end{tabular}

(3). Niepolomicka Forest-stretching beween Vistula and Raba in a valley at the Carpathian Foothill. There dominate podzols and brown soils formed of loess, as well as aluvial soils in river valleys. The forests consitute a dense complex consisting mainly of mixed forests (Pino-Quercetum), and to a smaller degree of oak-hornbeam forests (Tilio-Carpinetum).

(4). Sandomierska Forest - occupies a lowland area in the fork of Vistula and San, where prevail podzol and brown soils on loose and loamy sands, while aluvial soils stretch along river banks. There dominate mixed forests (Pino-Quercetum), pine forests (Vaccinio myrtilli-Pinetum) and beech forests (Fagetum carpaticum).

From these four mentioned areas jointly 617 roe-deer buck mandibles were collected. For histological studies 200 mandibles were selected in such a manner that all age classes were well represented (Table 1). During the selection it was also attempted to obtain material from possibly all districts in a given area. 
The division of the material into age classes was at first based on the estimates of hunting commissions. Then selected mandibles were, however, subjected to the second age estimations according to teeth wear and colour of dentine. This was accomplished by one highly qualified arbiter of the commission with the use of Rieck table. In this way the accuracy of age estimates made by hunting commissions was verified.

The absolute age estimates were obtained by studying histological sections of $I_{1}$ roots. Such sections permit to distinguish the rings of annual growth in the tooth cement or dentine. This method was used for the first time by Seargent \& Pimlott (1959) for the teeth of the elk, and then by Low \& Cow a A (1963) for the teeth of deer. Klevesal \& Kleinenberg (1967) and Blazis (1971) employed it for the estimation of roe-deed age. The methods used in the present study were based mainly on those described by the latter authors.

Incisors were pulled out from the mandible in such a way as to avoid root damage. For this reason some of the mandibles were soaked in water for approximately half an hour. Then the teeth were decalcified in $5 \% \mathrm{HNO}_{3}$ for 26 hours and washed for 24 hours in running water. The decalcified teeth were cut on a freezing microtome MPTY 42 into elongated sections $15 \mu$ thick. After staining with Delafield haemotoxyline they were rinsed in water and placed in the differentiating fluid $(75 \%$ alcohol with one drop of $\mathrm{HCl})$. Then they were again rinsed in water, transferred through water solutions of glycerol (25, 50 and $75 \%)$, and finally embedded in glycerolgelatine.

Permanent preparations were inspected under a projection MP 3 microscope at magnification $133 \times$. The most clear pictures of the year growth of cement are visiable in the preparations stored for a few months.

\section{RESULTS}

\section{Histological Structure of Roe-deer Teeth}

Longitudinal sections of $I_{1}$ show that the tooth is built of dentine covered by enamel on the crown, or by the layer of cement on the root. On the boundary of dentine and cement the granular layer of Toms is visiable. The layer of cement contains cavities with cementoblasts and is penetrated by Sharpey fibres coming from the periodentium.

Two types of ring are visiable within the cement layer. The first type corresponds to annual growth rings: alternatively arranged summer and winter rings. The latter age built mainly of fibrous elements, which are dense and intensely stained. Summer rings are more broad, built of a looser tissue, more rich in cellular elements, and are less intensely

EXPLANATION OF PLATE III

Fig. 2. Longitudinal sections through the roots of roe-deer teeth $\left(I_{1}\right)$. Arrows indicate winter rings.

A - two-year old stag, B - three-year old stag, C - five-year old stag. 1 - dentine, 2 - cement, 3 - Tomes line; rut lines in the circle. 


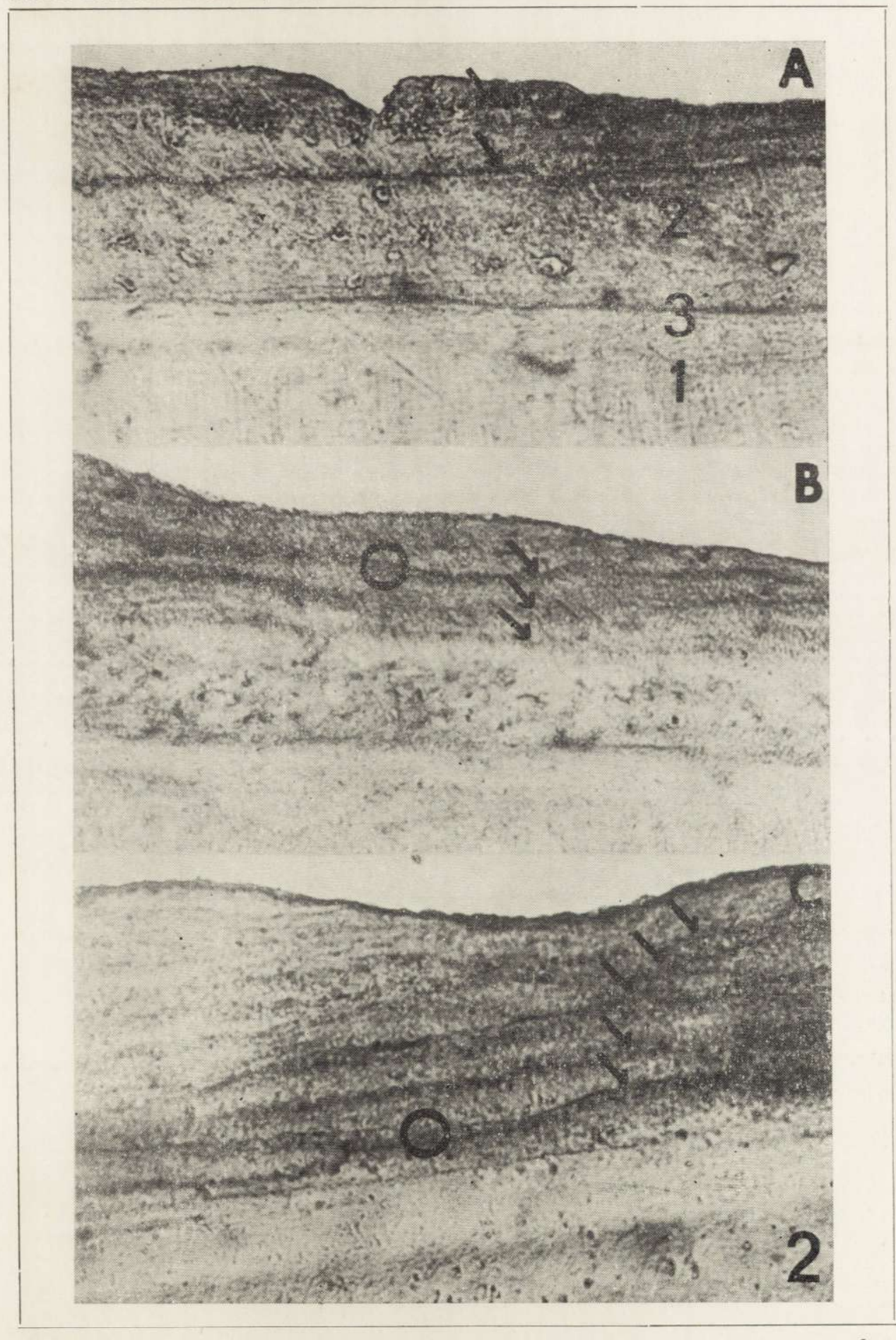




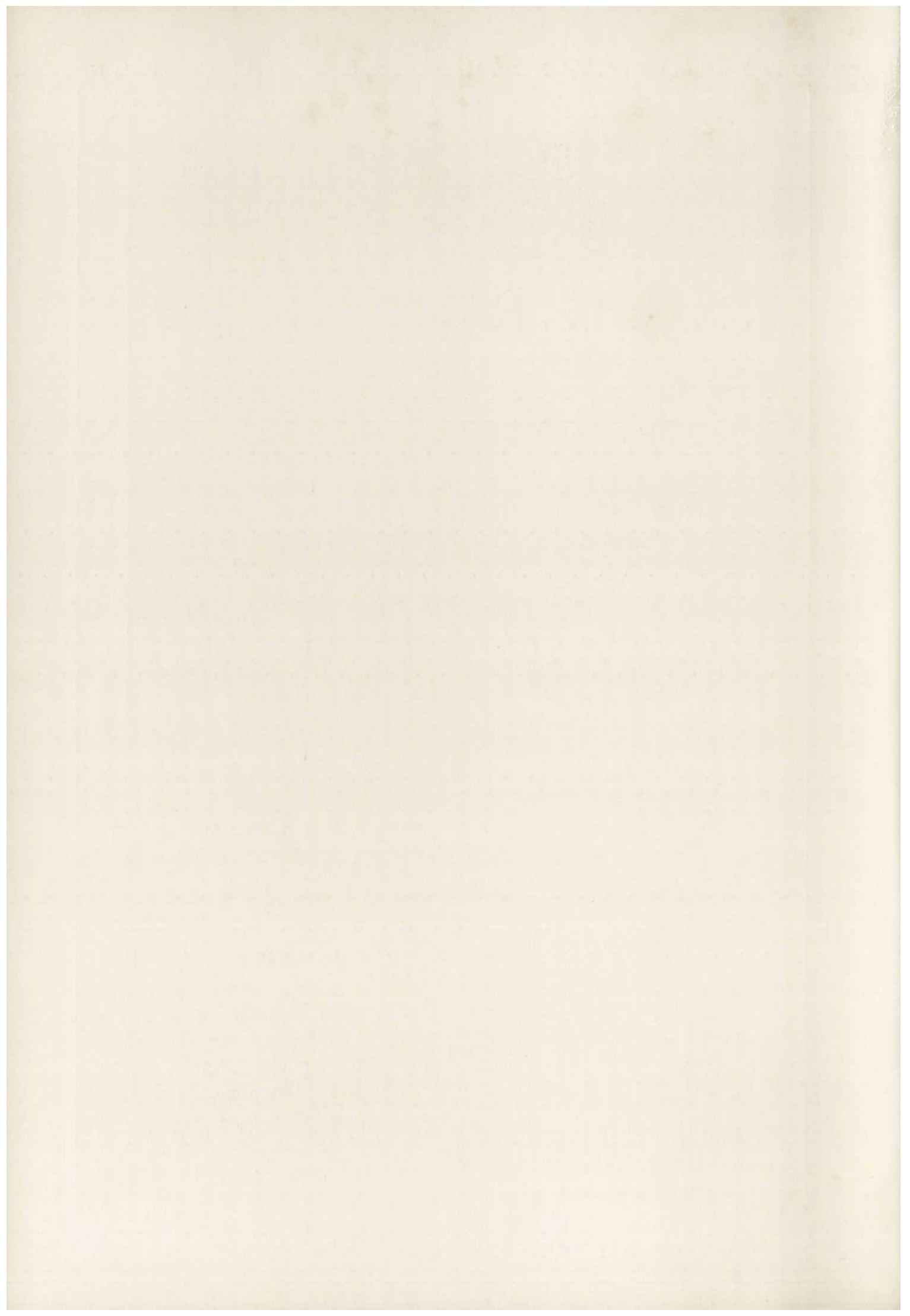


stained. The first summer ring differ from subsequent ones, is broader and more porous (Fig. 2A, Plate III).

The second type of rings are described as additional ones. There belong rut rings, visiable only in some preparations from buck teeth. They lie closely to winter rings are more narrow and poorly stained (Fig. 2B). The formation of these rings is associated with rut period during which bucks are fasting.

In some cases summer rings show lamellar organization, especially at higher magnifications. Such structure is probably related to changes of food type during the year, and to the way of deposition of the cement layer ( $\mathrm{L} \mathrm{ow} \& \mathrm{Cow}$ a, 1963 ).

As a rule the additional lines do not obscure the picture of annual growth rings which are used for the determination of the absolute age of an animal. The age of young roe-deer during the first few months of life is determined on the basis of eruption of parmenent and milk teeth.

In principle any tooth can be used for making histological preparation. Incisors $\left(I_{1}, I_{2}\right)$ and molars $\left(M_{1}, M_{2}\right)$ erupt in autumn before the first winter in the roe-deer life. The remaining teeth $\left(I_{3}, C, P M_{1}, P M_{2}, P M_{3}, M_{3}\right)$ erupt in the next year. In order to obtain proper age of the animal from the preparations of the latter teeth the number of winter rings should be increased by one.

In principle the estimation of age from good preparations of teeth does not provide any difficulties. Only preparations from one-year old animals, as well as from over 8-year old animals may give some troubles. In one year kids one may take by mistake lamellar structure of the summer ring as annual rings. In 8 year old animals (and in older ones) the rings of annual growth lie in a close proximity, and in case of the presence of rut rings, number of winter rings is difficult to ascertain. Moreover, in old animals cement layer increases in a non-uniform manner, thus the course of rings is very uneven.

\section{Relative and Absolute Estimates of Age}

Age estimates according to the number of annual growth rings counted in histological preparations were regarded as absolute values. The data based on the teeth wear were compared with them.

Age distribution of bucks obtained by relative and absolute estimates is compared in Fig. 3. In the estimates of a specialist 9 years constitutes the highest age class. To this class belong individuals 9-year old and older, since differences in teeth wear are then too small to be sufficient for accurate age estimation. 

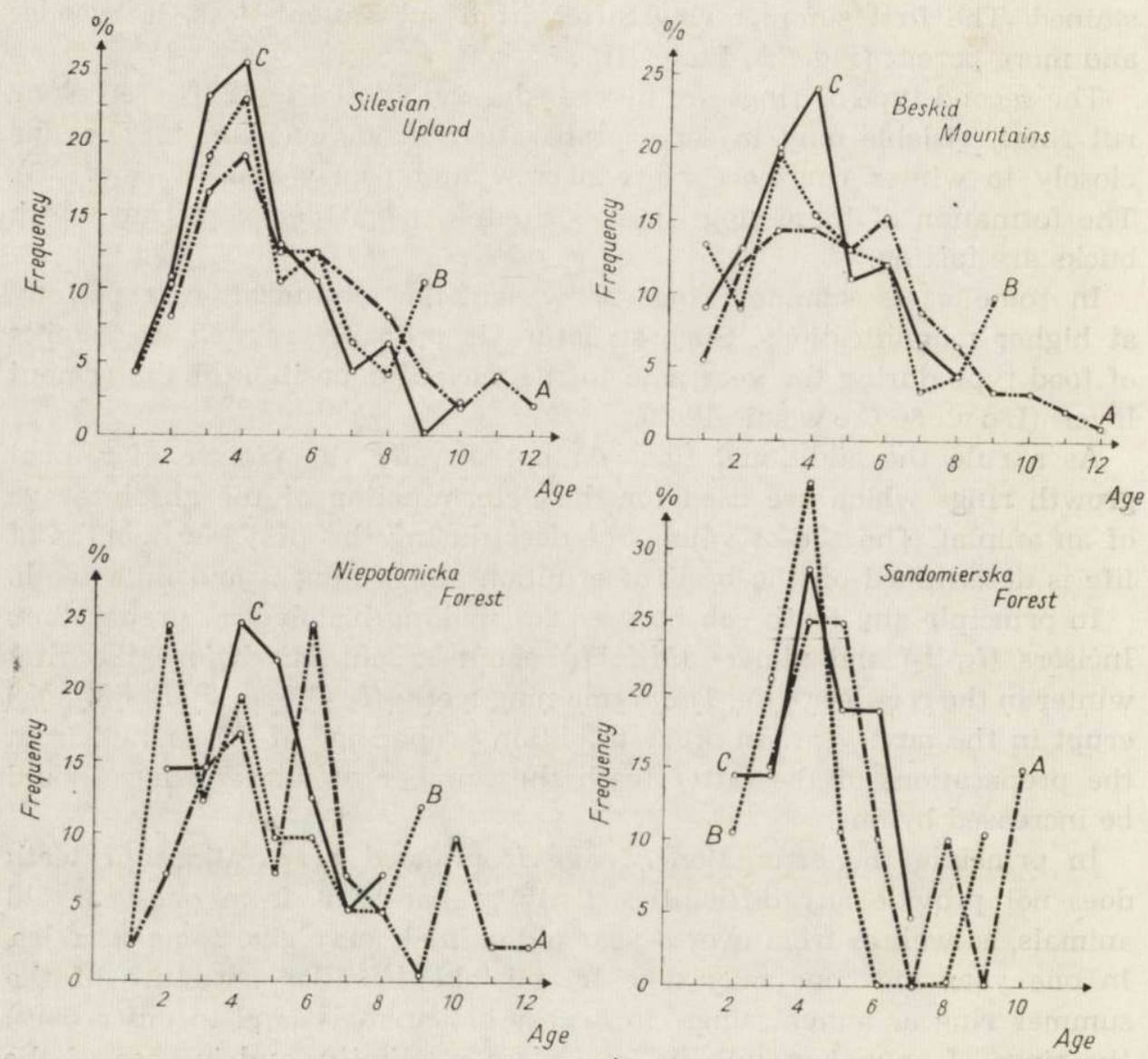

Fig. 3. Age structure of bucks from four studied areas determined on the basis of relative estimates, i.e. tooth wear - (A) - as estimated by commissions of Polish Hunting Association, (B) - by a specialist, and on the basis of absolute histological method (C).

In all cases the estimates made by commissions showed a shift toward older age classes in comparison with absolute values. The distribution of estimates made by a specialist is more close to the absolute values. Still in the area of Silesian Upland and Beskid Mountains more individuals were reckoned among older age classes while in the area of Niepołomicka and Sandomierska Forests more individuals were regarded as younger animals.

In order to estimate quantitatively the deviations of relative estimates from the absolute age the mean deviations were calculated for all age 


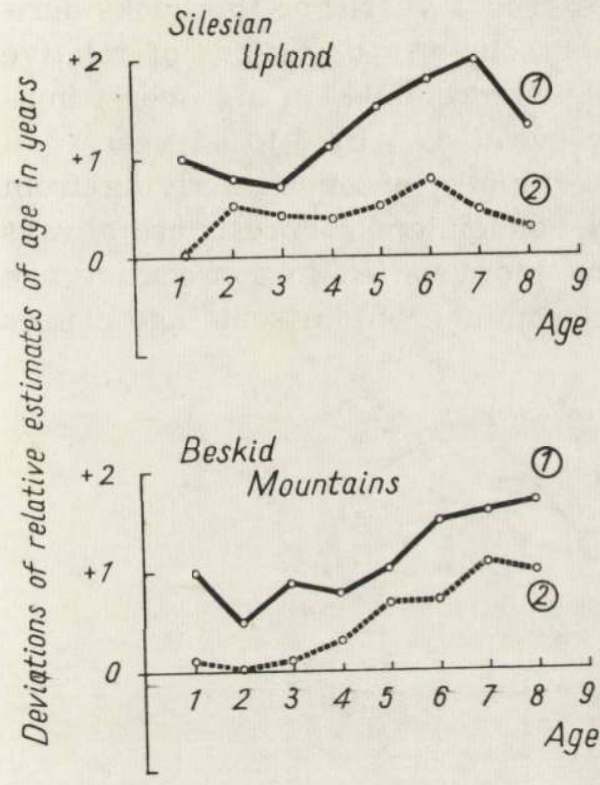

Fig. 4. Deviations of relative estimates of age in years from the absolute determinations for bucks from highland areas (Silesian Upland, Beskid Mountains) and lowland ones (Niepołomicka and Sandomierska Forest). Absolute determinations (histological method) represent the baseline.

1 - deviations of commission estimates, 2 - deviations of specialist estimates.

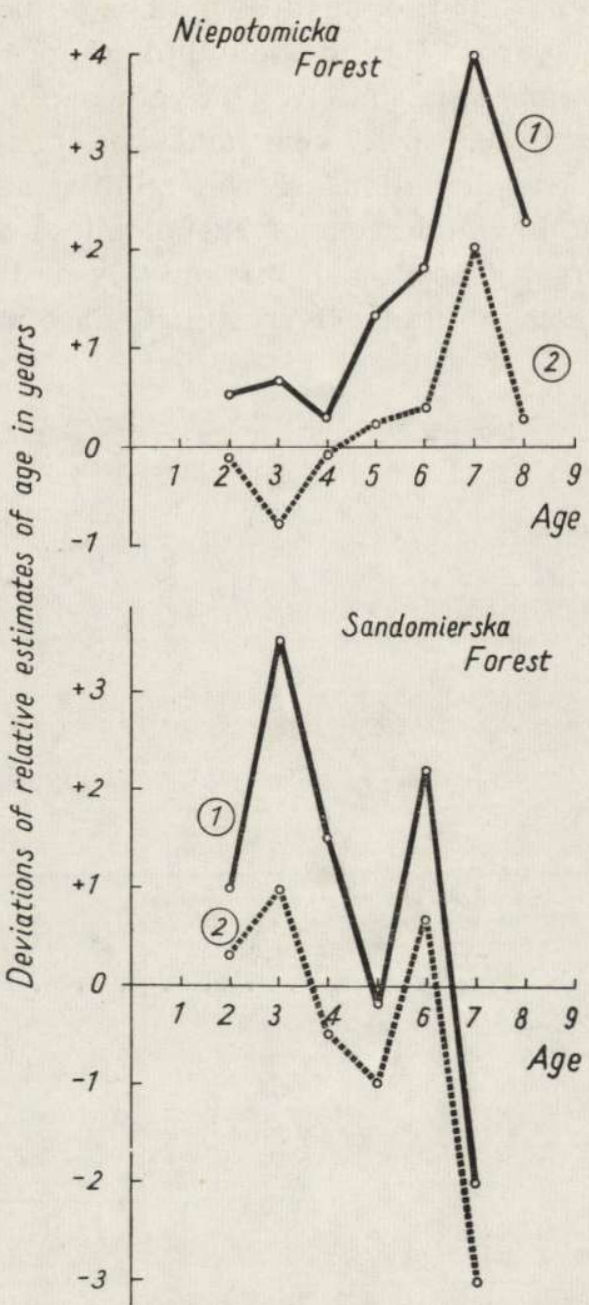

classes. First of all the difference was calculated between the absolute estimate and two relative estimates. The difference was regarded as the positive when relative estimates were higher than the absolute one, and negative - in the reverse case. Then for each age class the mean error was calculated by adding up all positive or negative errors and dividing the value by the number of individuals.

The curves of deviations of relative estimates from the baseline of absolute estimates (Fig. 4) show a similar course for the areas of Silesian Upland and Beskid Mountains. In the material from Silesian Upland the age values given by commissions overestimate by one year the age of roe-deer 1 to 4-year old, and by almost two years - the age of older animals, $6-7$-year old. The estimates given by a specialist show a similar 
trend but the mean deviations do not exceed 1 year. For the bucks deriving from Beskid Mountains (Fig. 4) the course of deviations of relative estimates is similar. The values given by the commission are overestimated by 0.5 to 1.7 year, and those of the specialist - by 0 to 1.1 year.

The deviations of the relative age estimates of bucks deriving from the lowland areas of Niepołomicka and Sandomierska Forests are always larger (they reach 3.5 and 4 years) and more varied in consecutive age classes (Fig. 4). Overestimates are most common but in some age classes

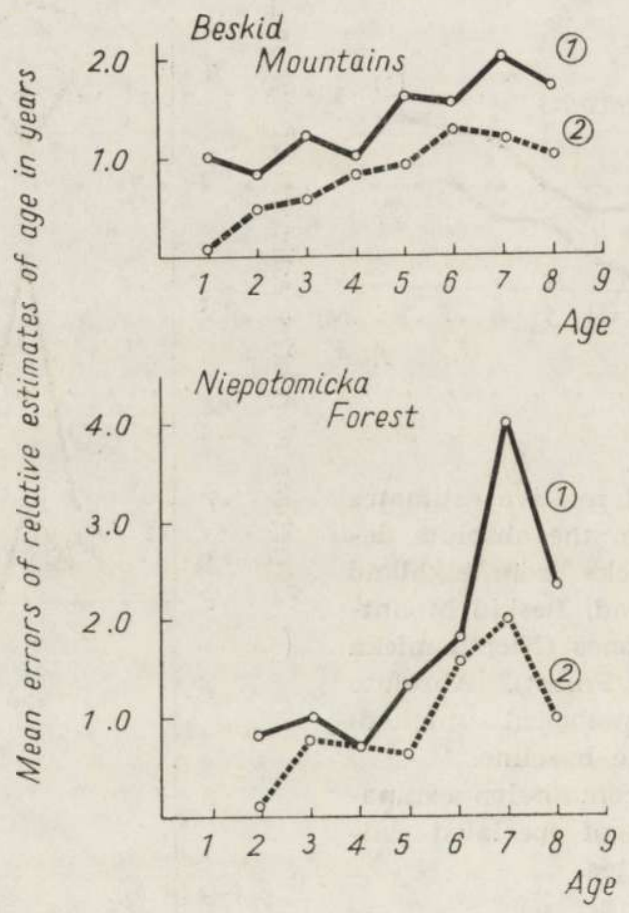

Fig. 5. Mean errors of relative estimates of buck age from the mountain area (Beskid) and lowland area (Niepolomicka Forest).

1 - commission estimates, 2 - specialist estimates (further explanations in the text).

the mean deviation is negative. The estimates of the specialist are surprisingly close to those of the commission, although he is always nearer the absolute values.

The age of bucks from the Niepołomicka Forest was estimated with the error not exceeding 1 year when the animals were less than 4-year old. However, in older age classes (5 to 7-year old) the error reached 2 years (specialist) and 4 years (commission). The material from Sandomierska Forest shows two strong overestimates of relative values: in the 
animals aged three or six years. The commissions overestimated the age by 3.5 and 2.2 years, respectively, and the specialist by 1.0 and 0.7 years. Underestimation of the age of 7-year old bucks is not representative since it concerns only one individual.

The described deviations of relative age estimates show that the method based on tooth wear is of small accuracy. An attempt was made to analyse why in certain age classes the arbiters committed most errors, independently whether those were under- or overestimates. For this purpose the deviations in each age class were added up independently of their sign (plus or minus) and the mean error was calculated. As a rule

Table 2

Comparison of accuracy of buck age determination in four selected areas.

\begin{tabular}{|c|c|c|c|c|c|c|c|}
\hline \multirow[b]{2}{*}{ Areas } & \multirow[b]{2}{*}{$N$} & \multicolumn{3}{|c|}{$\begin{array}{c}\text { A } \\
\text { Estimates of commission, } q\end{array}$} & \multicolumn{3}{|c|}{$\begin{array}{c}\text { B } \\
\text { Estimates of specialist, } q\end{array}$} \\
\hline & & Accurate & $\begin{array}{l}\text { Over- } \\
\text { estimated }\end{array}$ & $\begin{array}{l}\text { Under- } \\
\text { estima- } \\
\text { ted }\end{array}$ & Accurate & $\begin{array}{l}\text { Over- } \\
\text { estimated }\end{array}$ & $\begin{array}{l}\text { Under- } \\
\text { estima- } \\
\text { ted }\end{array}$ \\
\hline Silesian & & & & & & & \\
\hline $\begin{array}{l}\text { Upland } \\
\text { Beskid }\end{array}$ & 48 & 25.0 & 68.7 & 6.2 & 33.3 & 47.9 & 18.8 \\
\hline $\begin{array}{l}\text { Mountains } \\
\text { Niepołomicka }\end{array}$ & 91 & 28.6 & 61.5 & 9.9 & $\overline{39} .6$ & 42.9 & 17.6 \\
\hline $\begin{array}{l}\text { Forest } \\
\text { Sandomierska }\end{array}$ & 41 & 24.4 & 65.8 & 9.8 & 34.1 & 31.7 & 34.1 \\
\hline Forest & 20 & 20.0 & 60.0 & 20.0 & 30.0 & 25.0 & 45.0 \\
\hline Total/Avg. & 200 & 26.0 & 64.0 & 10.0 & 36.0 & 40.0 & 24.0 \\
\hline
\end{tabular}

it was found that the error increases in older age classes, and that the errors committed by the commissions are higher than of the specialist (Fig. 5).

All the diagrams indicate that the differences between the estimates of the commission and the specialist are not high, usually estimates of the commission and the specialist are not high, usually around half year, and the curves of errors run almost in parallel. These differences are caused by the fact that the specialist knew of the age overestimation with the employed criteria. In particular cases the estimates of the commission and of the specialist differ considerably; this may be explained by certain partiality of some commissions. 


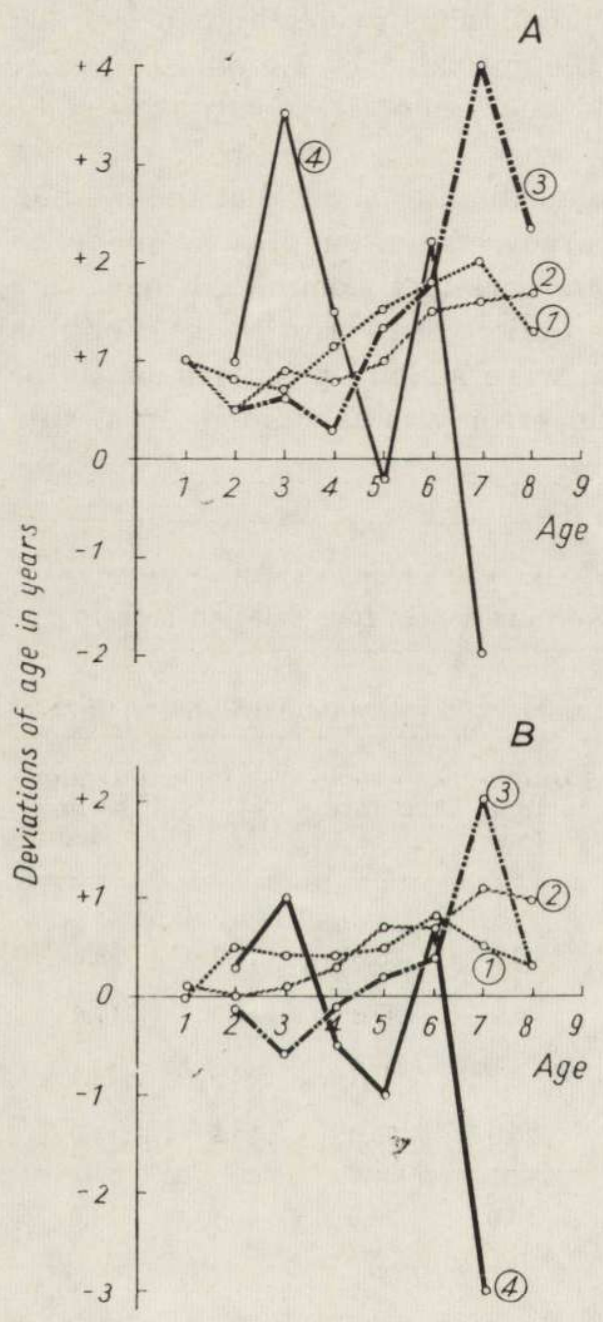

Fig. 6.

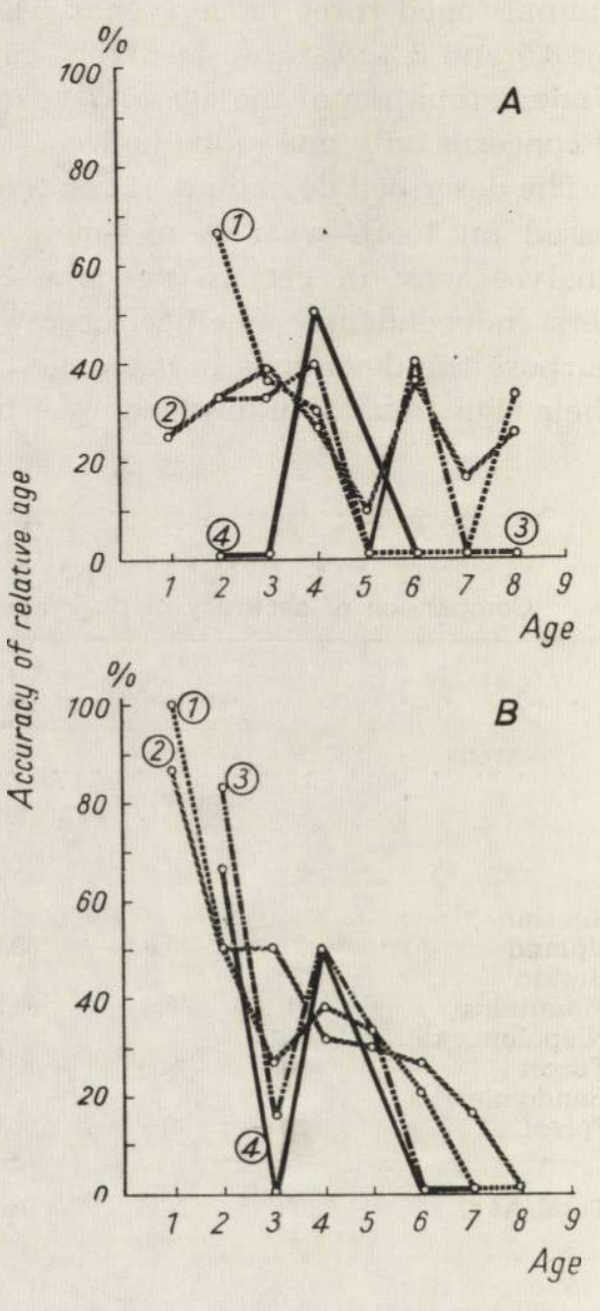

Fig. 7.

Fig. 6. Accuracy of relative age estimates of bucks in four studied areas. 1 - Silesian Upland, 2 - Beskid Mountains, 3 - Niepolomicka Forest, 4 - Sandomierska Forest. A - estimates of commissions of Polish Hunting Association, B - estimates of specialist.

Fig. 7. Deviations of buck age according to the estimates of commissions (A) and specialist (B) from the absolute age (zero line).

1 - Silesian Upland, 2 - Beskid Mountains, 3 - Niepołomicka Forest, 4 - Sandomierska Forest. 


\section{Accuracy of Relative Age Estimates}

The age estimates made by a commission and by specialist on the basis of tooth wear are accurate only in a small number of cases (Table 2). Among the analysed values prevailed overestimates, while underestimates were scarce. On the average, for the whole material from four analysed areas the commissions gave $26 \%$ of accurate age estimates, and the specialist $-36 \%$. Overestimates were found in $64 \%$ and $40 \%$ respectively, and underestimates - in only 10 and $24 \%$ (Table 2).

In particular areas the percentage of accurate estimates does not differ considerably (in the values given by commissions it ranges from $20.0 \%$ to $28.6 \%$; in the walues given by specialist - from $30.0 \%$ to $39.6 \%$ ). Both the commissions and the specialist showed the highest accuracy in the material from Beskid Mountains, and the lowest from the Sandomierska Forest. It is characteristic that in the estimates of the specialist the highest number of overestimated values fall for the mandibles from Silesian Upland and Beskid Mountains. For the bucks from the Niepolomicka and Sandomierska Forests a considerable number of values is understimated, partticularly by the specialist.

The percentage of accurate estimates decreases in older animals (Fig. 6). This is a general rule confirmed in all four areas; it occurs in age estimates by the commissions (Fig. 6A), and eve nmore distinctly in the estimates of the specialist (Fig. 6B).

\section{DISCUSSION}

\section{The Effect of Habitats on Teeth Wear of Roe-deer}

In many American and European investigations, where the histological analysis of teeth was used for age determinations of deer, small accuracy of relative age estimates was indicated (Mitchell, 1963; Low \& C ow a n, 1963; E rick s o n et al., 1970). Opinion on the superiority of the tooth wear method is rather isolated ( $\mathrm{L} \mathrm{ow} \mathrm{e}, 1967)$. The latter author reported that only $80 \%$ of estimates made by the histological method were accurate. However, the results of histological examination of teeth deriving from the animals of a known age presented in several papers confirm the credibility of this method (Reiners \& Nordby, 1968; B l a z i s, 1971).

The inaccuracy of age estimates by the method of teeth wear is explained either by low qualifications of an arbiter, who is also influen- 
ced by the appearance of antlers (Gilber t \& Stolt, 1970), or by the dependence of the degree of tooth wear on the abrasive materials consumed with food (B r i a n, 1966).

The analysis of buck mandibles deriving from four different areas in south-eastern Poland indicates that the differences between age determinations based on tooth wear and on histological examination are not accidental (Fig. 7). The diagrams of deviations of age estimates are distinctly different in particular areas. It appears that the degree of tooth wear depends on the habitat in which a given population of roe-deer lives. The lowest rate of tooth wear was observed in Beskid Mountains and Silesian Upland, and a higher rate in Niepołomicka Forest. The highest degree of tooth wear (already in younger age classes) was shown by roe-deer in Sandomierska Forest.

The degree of teeth wear may depend on food type and hardness of teeth. It is know that the occurrence of plant communities on a given area depends to a considerable extent on the type of ground, and more precisely on the bed rock and soil formed from it (D o br z a n s ki, 1966). It is also known that the content of mineral compounds in plants correspond to the mineral content of soil ( $\mathrm{C} \mathrm{urt}$ is \& C la r k, 1958). Roe-deer consumes plant food and utilizes mineral compounds present in plants. This concerns particularly calcium and phosphorus compounds, which are important for the structure of bones and teeth. On the other hand, abundance of silica in soil is reflected in the composition of plant cell walls, and hence in the hardness of plant food.

This whole complex of various factors exerts a considerable effect on the degree of tooth wear in roe-deer. For this reason in the areas of fertile soils, with varied vegetation, rich in calcium and phoshorus compounds (e.g. Beskid Mountains, Silesian Upland), the rate of tooth wear in roe-deer is slower. On the other hand, on sandy soil the food available for these animals is less varied ( $\mathrm{Siuda} \& \mathrm{Z} u$ row s k i, 1969; Bobek, Weiner \& Zieliński, 1972), saturated with silica coumpounds and less abounding in calcium and phosphorus. In these areas roe-deer wears teeth at a higher rate (Niepołomicka Forest, and mainly Sandomierska Forest).

The observed relationship (Fig. 7) permits to suppose that teeth wear in roe-deer depends directly on tooth hardness and type of consumed food, but indirectly is related to the type of soil on a given area. This hypothesis may be easily ascertained by determining tooth hardness of roe-deer from different areas and comparing it with mineral content of plants which in a given habitat constitute food for roe-deer. 


\section{Application of Histological Method for the Determination of Absolute Age}

\section{of Roe-deer}

The histological method is hitherto a unique way of determination of absolute age of deer. The method can be fully recommended in various scientific investigations when the accurate determination of age is important. However, the method of absolute age determination is time consuming and cannot be employed for large groups of individuals. In such cases a standard can be prepared for all age classes with the use of certain number of mandibles and histological method. The standards should be prepared separately for each studied area of a given soil type. Then the age of remaining animals can be estimated by the relative method using appropriate standards.

The determination of age with such simplified method does not provide accurate values in all cases on account of considerable individual variability in the degree of tooth wear in roe-deer deriving from the same area.

Acknowledgements: I wish do express cordial thanks to Dr. W. Grodzin nski for scientific guidance during these investigations. I am also grateful to Provincial Hunting Councils in Katowice, Kraków and Rzeszów, as well as to Regional Board of State Forests in Kraków for rendering accessible the material of buck mandinles. Mr. A. Tom e k, M. Sc. (Agricultural Academy, Kraków) was kind enough to perform the second estimation of age of 200 roe-deer mandibles selected for histological studies. I am also grateful to Dr. A. B l a z is (Institute of Zoology and Parasitology, AN LSSR) for valuable methodological instructions, and to Mr. J. B ig a j, M. Sc. (Jagiellonian University) for help in histological technique.

\section{REFERENCES}

1. Blazis A. S., 1971: A method of vital extraction of tooth in Capreolus capreolus for age determination. [In Russian with English summ.]. Zool. Zh., 50, 6: $926-929$.

2. Bobek, B., Weiner, J. \& Zieliński, J., 1972: Food supply and their consumption by deers in a decidous forest of Southern Poland. Acta theriol., 17, 15: $187-202$.

3. Brian, R. A., 1966: Determining age of white-tailed deer from layers in cementum of molars. J. Wildl. Mgmt., 30, 1: 197-199.

4. Curtis, O. F. \& Clarck, D. G., 1958: Wstęp do fizjologii roślin. 1-812, PWRiL, Warszawa.

5. Dobrzański B., 1966: Zarys geografii gleb. PWN: 1-175. Warszawa.

6. Erickson J. A., Anderson A. E., Medin D. E. \& Bowden D. C., 1970: Estimating ages of mule deer an evalution of technique accuracy. J. Wildl. Mgmt., 34, 3: 523-531.

7. Gilbert F. F. \& Stolt S. L., 1970: Variability in aging male white-tailed deer by tooth-vear characteristics. J. Wildl. Mgmt., 34, 3: 532-534.

8. Klevesal G. A. \& Kleinenberg S. E., 1967: Opredelenie vozrasta mlekopitajuscih po sloistym strukturam zubov i kosti. 1-142, Izd. Nauka, Moskva. 
9. Low W. A. \& Cowan Mc T., 1963: Age determination of deer by annular structure of dental cementum. J. Wildl. Mgmt., 27, 3: 466-471.

10. Low e V. P. W., 1967: Teeth as indicators of age with special reference to red deer (Cervus elaphus) of know age from Rhum. J. Zool. Lond., 152: 137-153.

11. M c Ewan E. H., 1963: Seasonal annuli in the cementum of the teeth of borren ground caribu. Can. J. Zool., 41, 1: 111-113.

12. Mitchell B., 1963: Determination of age in scottich red deer from growth layers in dental cement. Nature, 198, 4878: 350-351.

13. Pas ławski T., 1971: Łowiectwo dla leśników i myśliwych. PWRiL: 1-328, Warszawa.

14. Pi elowski Z., 1970: Sarna. 1-220, PWRiL, Warszawa.

15. Reimers E. \& Nordby Q., 1968: Relationship between age and tooth cementum layers in Norwegian reindeer. J. Wildl. Mgmt., 32, 4: 957-961.

16. Sergeant D. E. \& Pimlott D. H., 1959: Age determination in moose from section incisor teeth. J. Wildl. Mgmt., 23, 3: 315-321.

17. Si uda A. \& Z Z rowski W., 1969: The food of the roe deer. Acta theriol., 14, 18: $247-262$.

18. S z a f e r W., 1959: Szata roślinna Polski. PWN: 1-920, Warszawa.

Accepted, March 20, 1973

Department of Animal Ecology,

Jagiellonian University,

Krupnicza 50, 30-060 Kraków, Poland.

Ewa SZABIK

OCENA WIEKU SARN Z ROŻNYCH ŁOWISK POLSKI POEUDNIOWO-WSCHODNIEJ

\section{Streszczenie}

Spośród 1506 żuchw rogaczy sarn, Capreolus capreolus (Lin na e us, 1758) odstrzelonych w poludniowo-wschodniej Polsce w latach 1969-1971 wybrano 200 (Tabela 1) reprezentujących cztery różne siedliska (Fig. 1). Wiek tych rogaczy określono najpierw na podstawie starcia zębów, a potem bezwzględnie, według liczby słoi zimowych $\mathrm{w}$ cemencie $I_{1}$ (Fig. 2). Oceny wieku uzyskane dwiema metodami były zgodne jedynie w $20-40 \%$ (Tabela 2, Fig. 3, 4). Zawyżanie wieku rogaczy na podstawie starć zębów w młodszych klasach wieku (1-4 lat) wynosi około 1 ro$\mathrm{ku}$, natomiast w starszych (5-9 lat) osiąga 2-4 lata. Stwierdzono mniejsze błędy ocen względnych dla rogaczy z terenów wyżynnych i górskich, niż z terenów nizinnych (Fig. 5). Szybkość ścierania zębów u sarn zależy bezpośrednio od twardości ich zębów oraz od jakości pokarmu, jakim się odżywiają. Wiąże się to ze składem mineralnym gleb na danym obszarze. Istnieje też pewna zmienność osobnicza w ścieraniu zębów u sarn pochodzących $\mathrm{z}$ jednego siedliska. Błędy ocen komisji łowieckich są większe, niż wybranego specjalisty (Fig. 5, 6, 7), chociaż kierunek obu odchyleń jest zawsze zgodny. 